\title{
COMPETITIVENESS OF MEAT AND ASSOCIATED PRODUCTS IN INTERNATIONAL TRADE
}

\author{
AtTila JAMbor \\ Corvinus University of Budapest \\ Department of Agricultural Economics and Rural Development \\ 1093 Budapest Fővám tér 8. \\ attila.jambor@uni-corvinus.hu
}

\begin{abstract}
There has been considerable growth in global meat trade recently in line with globally increasing population and changing diets. The paper analyses competitiveness patterns in global meat trade between 1989 and 2018. The article applies the method of revealed comparative advantages on global meat trade data and reaches a number of conclusions. First, results show top 10 countries in global meat exports and imports as well as most traded products. Global meat exports are dominated by the United States, Brazil and the Netherlands, whole main meat importers were Japan, Germany and the United Kingdom. The paper shows that global meat trade is highly concentrated by country and product but this concentration has decreased considerably in the previous 20 years. By analysing specialisation in global meat trade, a diverse picture becomes apparent where export positions and comparative advantages are not always moving together. Last but not least, Hungarian positions are also analysed in context throughout the paper.
\end{abstract}

Keywords: competitiveness, comparative advantage, meat, trade

\section{INTRODUCTION}

Competitiveness is one of the most used word in economics, containing many kinds of different interpretations. One strand of the literature combines international trade theories with macro level competitiveness and argues that competitiveness of nations can be interpreted and measured via trade based indices. BALASSA (1965) was one of the early supporters of this theory, elaborating his famous index of revealed comparative advantages. Since this seminal work, a vast amount of literature is dedicated to the analyses of revealed comparative advantages of global trade.

The analysis of comparative advantages of agricultural and food products is limited in the international literature. In a regional context, CHINGARANDE (2013) investigated the comparative advantage of the East-African Community (EAC) Member States and found advantage for some agricultural products such as green tea, coffee, ivory, fish fillet, and flowers. AKMAL ET AL. (2014) analysed the competitiveness of Pakistan's basmati rice exports and found that the country was losing its position to world markets in one of its biggest export products, calling for a change in its trade strategy. ASTANEH ET AL. (2014) searched for comparative advantage in Iran's stone fruits market and found that the country had strengthened her competitive positions, though it lacked comparative advantage in the majority of the years analysed.

In Europe, BOJNEC AND FERTŐ (2014) analysed the competitiveness of agri-food exports of European countries, and found majority of countries and products to have an advantage globally. The most successful nations in this regard were the Netherlands, France and Spain. The article also predicted a more long lasting advantage for Western-European countries, compared to Eastern-European ones. FERTŐ (2008) analysed the evolution of agri-food trade patterns in Central European Countries and found the trade specialization 
across the region to be mixed. For particular product groups, greater variation was observed, with stable (unstable) patterns for product groups with comparative disadvantage (advantage). TÖRÖK AND JÁMBOR (2013) also analysed the agri-food trade patterns of New Member States, and highlighted that almost all countries experienced a decrease in their comparative advantage after the EU accession, though it still remained at an acceptable level for most cases.

In the Americas, KORINEK AND MELATOS (2009) analysed revealed comparative advantages of MERCOSUR countries and found margarine, vegetable oils and coffee as the most competitive products in 1988 to 2004. In particular, Brazil and Argentina are leaders in comparative advantage in beef, both in fresh and preserved form. Moreover, SPARLING AND THOMPSON (2011) investigated the Canadian agri-food sector and concluded that despite its overall competitiveness, the country was losing its position in food processing. SARKER AND RATNASENA (2014) analysed the comparative advantages of Canadian wheat, beef and pork sectors between 1961 and 2011, and found only the wheat sector to be competitive.

DISDIER ET AL. (2015) analyzed comparative advantages of agri-food products in the Asian and Pacific region and found that Australia and New Zealand had strong comparative advantages in fruit and vegetables, beverages and the dairy market.

Despite the apparent importance of the topic, however, the majority of studies are focused on industrial products. JAMBOR AND BABU (2016) were the first to make an overview on global agri-food trade competitiveness. This paper analyses revealed comparative advantages in global meat trade and in doing so, contributes to the existing literature in two ways. First, it applies the theory of revealed comparative advantages on an important agricultural product group. Second, it analyses global trade flows instead of regional or national ones.

\section{MATERIAL AND METHOD}

Probably the most well-known index analysing trade-based competitiveness of nations is Revealed Comparative Advantage (RCA), calculating the proportion of a country's share of exports for a single commodity to the exports of all commodities and the similar share for a group of selected countries, expressed by BALASSA (1965) as follows:

$$
\mathrm{RCA}_{\mathrm{ij}}=\left(\frac{X_{i j}}{X_{i t}}\right) /\left(\frac{X_{n j}}{X_{n t}}\right)
$$

where, $X$ means export, $i$ indicates a given country, $j$ is a given product, $t$ is a group of products and $n$ is the group of selected countries. Hence, a revealed comparative advantage (or disadvantage) index of exports can be calculated by comparing a given country's export share by its total exports, with the export share by total exports of a reference group of countries. If $\mathrm{RCA}>1$, a given country has a comparative advantage compared to the reference countries, or in contrast, a revealed comparative disadvantage if $\mathrm{RCA}<1$. Although the Balassa (RCA)-index is criticized from many aspects, it is beyond the scope of this paper to go into details - see Jambor and Babu (2016) for a thorough review on this issue. 
In order to calculate the index above, the article uses the World Bank WITS software based on COMTRADE, an international trade database developed by the United Nations at the HS six digit level as a source of raw data. Meat trade is defined as trade in HS02 products. The chapter works with trade data for the period of 1989 to 2018.

\section{RESULTS}

Global meat export has been continuously increasing in the previous 30 years with 10 countries giving the majority of products traded (Figure 1). The United States, Brazil and the Netherlands were the biggest meat exporters in 1989-2018, accounting for $30 \%$ of global meat export on average. The case of Spain and Brazil should be highlighted here as they were the countries increasing the export of meat products by 17 and 15 times between 1989-1993 and 2014-2018, respectively. Hungary was giving less than a percent of global meat exports in 1989-2018.

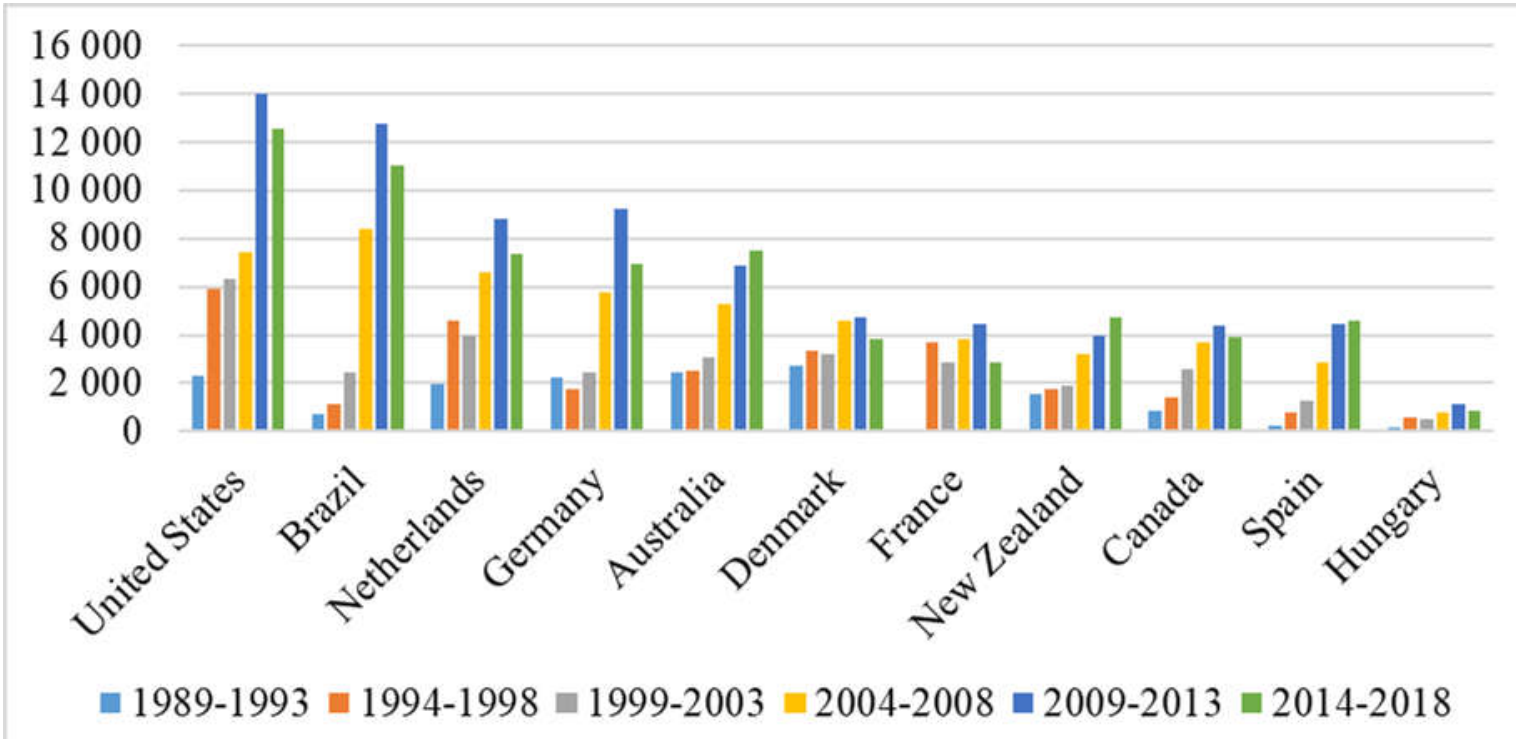

Figure 1. Meat exports of the most important market players and Hungary, 19892018, million USD based on World Bank (2019) data

As to global meat import, Japan, Germany and the United Kingdom were the major players, giving almost a third of the import of global meat and associated products (Figure 2). Although all countries have increased meat import to some extent in the period analysed, the case of China is amazing in this regard: from 1989-1993 to 2014-2018, China increased its meat import by almost 260 times! In the meantime, Hungary also experienced a significant 30 times growth in its meat import - however, this is still less than $0.5 \%$ of global meat traded. 


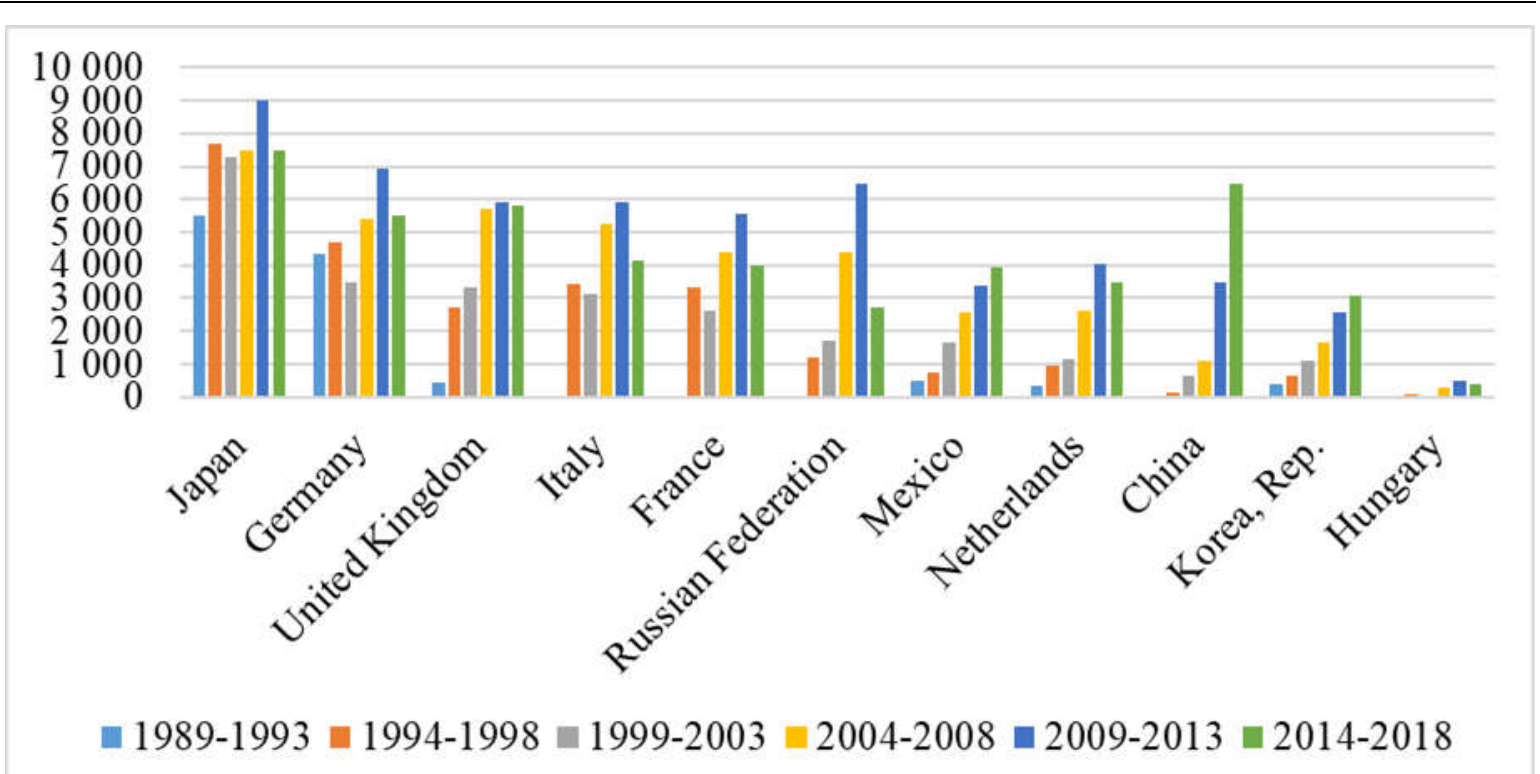

Figure 2. Meat imports of the most important market players and Hungary, 19892018, million USD based on World Bank (2019) data

With calculation of Balassa indices, competitiveness patterns of global meat trade becomes apparent (Table 1). It is obvious that New Zealand, Brazil and Australia had the highest Balassa indices in 2014-2018 with all the major exporters but Germany having some comparative advantage in the whole period. Brazil experienced the biggest growth in meat trade competitiveness the period analysed, while Hungary showed the biggest fall. Comparative advantages of New Zealand and Australia is mainly based on goat, sheep and lamb trade, while Brazil seems to have excelled in frozen chicken, swine and bovine meats. It is also evident from Table 1 that biggest exporters of meat in value terms are not necessarily the most competitive countries globally.

Table 1. Balassa indices for meat products of the most important market players and Hungary, 1989-2018, based on World Bank (2019) data

\begin{tabular}{|c|c|c|c|c|c|c|}
\hline Country & $\begin{array}{c}1989- \\
1993\end{array}$ & $1994-1998$ & $1999-2003$ & $2004-2008$ & $\begin{array}{c}2009- \\
2013\end{array}$ & $\begin{array}{c}2014- \\
2018\end{array}$ \\
\hline United States & 0.80 & 0.87 & 0.99 & 0.79 & 1.03 & 1.03 \\
\hline Brazil & 1.94 & 1.64 & 3.50 & 4.55 & 4.16 & 4.25 \\
\hline Netherlands & 2.44 & 2.11 & 1.58 & 1.32 & 1.23 & 1.38 \\
\hline Germany & 0.39 & 0.27 & 0.42 & 0.51 & 0.65 & 0.54 \\
\hline Australia & 7.00 & 7.62 & 8.65 & 8.89 & 6.64 & 7.63 \\
\hline Denmark & 5.32 & 4.43 & 4.27 & 3.34 & 3.08 & 2.68 \\
\hline France & n.a. & 1.33 & 1.34 & 1.38 & 1.34 & 1.16 \\
\hline New Zealand & 21.15 & 30.76 & 34.18 & 36.58 & 31.10 & 26.50 \\
\hline Canada & 0.56 & 0.60 & 0.81 & 0.84 & 0.93 & 1.02 \\
\hline Spain & 0.74 & 1.00 & 1.61 & 1.85 & 1.86 & 2.05 \\
\hline Hungary & 15.48 & 10.68 & 5.97 & 3.37 & 3.12 & 2.75 \\
\hline
\end{tabular}




\section{CONCLUSIONS}

Results above suggest that the global meat market has considerably changed in the previous 30 years. In general, concentration by export and import decreased, suggesting that meat trade is made by an increasing amount of market players. Meat is mainly produced and traded among developed countries with changing roles in the global market.

According to the Balassa indices, New Zealand, Australia and Brazil were the most competitive countries in global meat exports in the previous 30 years with Brazil leading the line in competitiveness growth. It seems evident that little relationship exists between export values and competitiveness.

Although the methodology has a number of limitations, results show an interesting picture of global meat trade on the long run. Future research might focus on the determinants of changes behind together with comparing trade and competitiveness of other industries with the example above.

\section{ACKNOWLEDGEMENTS}

This research was supported by the National Research, Development and Innovation Office Project No. 119669 'Competitiveness of Agriculture in International Trade: A Global Perspective'.

\section{REFERENCES}

Akmal, N., Akhtar, W., Shah, H., Niazi, M.A., SAleEM, T. (2014): The Structure and Competitiveness of Pakistan's Basmati Rice Exports. Asian Journal of Agriculture and Rural Development 4(4): 304-312.

Astaneh, H.K., Yaghoubi, M., Kalateharabi, V. (2014): Determining Revealed Comparative Advantage and Target Markets for Iran's Stone Fruits. Journal of Agriculture, Science and Technology 16: 253-264.

BALASSA, B. (1965): Trade Liberalization and Revealed Comparative Advantage. The Manchester School 33: 99-123.

BoJNEC, Š., FeRTŐ, I. (2008): European Enlargement and Agro-Food Trade. Canadian Journal of Agricultural Economics 56, 4: 563-579.

BOJNEC, Š., FerTŐ, I. (2014): Agri-Food Export Competitiveness in European Union Countries. Journal of Common Market Studies, no. 3: 476-492

Chingarande, A., Mzumara, M. And Karambakuwa, R. (2013): Comparative Advantage and Economic Performance of East African Community (EAC) Member States. Journal of Economics 4(1): 39-46.

Disdier, A-C., Emlinger, C. AND Fouré, J. (2015): Atlantic versus Pacific Agreement in Agri-food Sectors: Does the Winner Take it All? Selected Paper prepared for presentation at the 2015 Agricultural \& Applied Economics Association and Western Agricultural Economics Association Annual Meeting, San Francisco, CA, July 26-28.

FERTÖ, I. (2008): The evolution of agri-food trade patterns in Central European countries. Post-Communist Economies 20, no. 1: 1-10. 
JAMBOR, A., BABU, S. (2016): Competitiveness of Global Agriculture: Policy Lessons for Food Security. Springer, Germany.

KorineK, J., Melatos, M. (2009): Trade Impacts of Selected Regional Trade Agreements in Agriculture, OECD Trade Policy Working Papers, No. 87, OECD publishing

SARKER, R., RATNASENA, S. (2014): Revealed Comparative Advantage and Half-a-Century Competitiveness of Canadian Agriculture: A Case Study of Wheat, Beef, and Pork Sectors. Canadian Journal of Agricultural Economics 62(4): 519-554.

SpARling, D., Thimpson, S. (2011): Competitiveness of the Canadian Agri-Food Sector. The Canadian Agri-Food Policy Institute.

TÖRÖK, Á., JÁmbOR, A. (2013): Agri-Food Trade of the New Member States since EU Accession. Agricultural Economics (Czech) 3: 101-112. 